\title{
Penerapan Asuhan Dalam Proses sistem keperawatan di Rumah Sakit
}

\author{
Tasya Nia Nuddin Halawa \\ tasyahalawa1705@gmail.com
}

\section{Latar Belakang}

Rumah Sakit merupakan suatu sistem pelayanan dimana yang berpusat pada memberikan pelayanan ataupun layanan yang baik terhadap pasien maupun masyarakat. Upaya Rumh Sakit dalam meningkatkan mutu pelayanan nya yaitu dengan cara menerapkan sistem perencanaan dalam memberikan asuhan keperawatan saat di Rumah Sakit. Sistem pelayanan ini diharapkan agar mampu meningkatkan kualitas serta mutu pelayanan yang diberikan harus sesuai prosedur dan tindakan. Dalam penerapan asuhan keperawatan ini diharapkan agar mampu meningkatkan kualitas yang tinggi serta mampu memberikan pelayanan yang profesional bagi masyarakat.

Asuhan keperawatan adalah suatu pendekatan untuk pemecahan masalah yang memampukan perawat untuk mengatur dan memberikan asuhan keperawatan. Salah satu manfaat dari penerapan asuhan keperawatan yang baik adalah meningkatkan mutu dan kualitas pelayanan dalam bidang keperawatan (Kozier, 2010). Tenaga perawat mempunyai kedudukan penting dalam menghasilkan kualitas pelayanan kesehatan dirumah sakit.Asuhan keperawatan yang bermutu dapat tercapai dengan pelaksanaan proses keperawatan. Proses keperawatan dapat memberikan asuhan keperawatan yang sesuai dengan kebutuhan klien, sehingga tercapai mutu pelayanan keperawatan yang optimal (Suarli \& Bahtiar, 2009).

Proses keperawatan merupakan suatu jawaban untuk pemecahan masalah dalam keperawatan, karena proses keperawatan merupakan metode ilmiah yang digunakan secara sistematis dan menggunakan konsep dan prinsip ilmiah dalam mencapai diagnosa masalah kesehatan pasien, merumuskan tujuan yang ingin dicapai, menentukan tindakan dan mengevaluasi mutu serta hasil asuhan keperawatan. Dalam pratiknya perawat menggunakan pengetahuannya tentang proses keperawatan untuk mengkaji kesehatan klien, menegakkan diagnosa, 
merencakan asuhan keperawatan, menerapkan dan mengevaluasi tindakan keperawatan yang diberikan.

\section{Metode}

Metode yang digunakan yaitu literature review, yaitu dengan menganalisis buku-buku dan jurnal online yang berkaitan dengan pengantar dan langkah-langkah proses keperawatan di rumah sakit. Dalam Penulisan Jurnal ini diawali dengan pemilihan topik, kemudian menuliskan kata kunci “Proses Keperawatan”, “asuhan keperawatan” dan "Penerapan Proses sistem Keperawatan". Dari hasil pencarian jurnal online kemudian diolah dan dianalisis sehingga menghasilkan sebuah pembahasan dan kesimpulan dari topik yang ditetapkan. Sumber penelitian ini berasal dari beberapa literature jurnal. Jurnal ini dibatasi dengan tahun paling tua 2012. Jumlah referensi jurnal yang digunakan sebanyak 12 referensi jurnal. Berdasarkan tujuan penelitian, maka penelitian ini merupakan penelitian eksplorasi untuk mengetahui mengenai proses keperawatan dan langkah-langkah proses keperawatan di rumah sakit yang dapat dilihat dari referensi.

Hasil

Jurnal dengan judul Penerapan Asuhan Dalam Proses sistem keperawatan di Rumah Sakit bertujuan untuk mengetahui tahapan Penerapan Asuhan Dalam Proses sistem keperawatan di Rumah Sakit yang akan diberikan kepada klien agar pemenuhan pelayanan dapat berjalan dengan baik. Hasil nya adalah perencanaan asuhan keperawatan dikategorikan baik karena penerapan keperawatan sangat penting pada asuhan keperawatan terhadap pasien sebelum melakukan tindakan. Judul dengan jurnal Pengetahuan Dan Sikap Perawat Terhadap Penerapan Asuhan Dalam Proses sistem keperawatan di Rumah Sakit. Tujuannya adalah untuk mendorong perawat dan mahasiswa agar melakukan penerapan keperawatan yang tepat sesuai dengan standar konsep dasar. Hasil dari data yang telah dikumpulkan dari berbagai sumber, banyak perawat yang telah melakukan penerapan keperawatan dalam memberikan asuhan keperawatan yang tepat pada pasien. Jurnal dengan judul Pengetahuan Dan Sikap Perawat Terhadap Penerapan Asuhan 
Keperawatan, bertujuan untuk mengetahui tentang penerapan sistem, asuhan keperawatan, dan mengapa pentingnya Penerapan Asuhan Dalam Proses sistem keperawatan di Rumah Sakit.

Perawat harus dapat mengkaji apa saja yang menjadi permasalahan klien sehingga dapat terpenuhinya kebutuhan kesehatan dan keperawatan klien. Dalam pengumpulan data perawat perlu memperhatikan tipe-tipe data yang terdiri dari data dasar, data fokus, data subjektif dan data objektif dari klien dengan pendekatan yang dilakukan perawat untuk memperoleh informasi status kesehatan klien .Perawat juga perlu memperhatikan karakteristik data yang dikumpulkan apakah sudah lengkap yaitu memuat seluruh informasi klien. Akurat dan nyata yaitu apakah dalam pengumpulan data perawat tidak ada keraguan dalam penulisan informasi mengenai status kesehatan pasien. serta relevan yang berfokus pada permasalahan yang dialami klien, dikarenakan Data yang salah atau kurang tepat dapat mengakibatkan kesalahan dalam penetapan suatu diagnosis yang nantinya akan berdampak pada tahap proses keperawatan selanjutnya.

proses keperawatan yang bertujuan untuk mengumpulkan informasi atau data tentang klien, agar dapat mengidentifikasi, mengenali masalah- masalah, kebutuhan kesehatan dan keperawatan klien, baik fisik, mental, sosial dan lingkungan. Dalam melakukan pengkajian, pengumpulan data sangat diperlukan. Pengumpulan data dimulai sejak klien masuk ke rumah sakit (initi al assessment), dirawat secara terus-menerus (on going assessment), serta pengkajian ulang untuk menambah / melengkapi data (re-assessment) yang bertujuan untuk mengumpulkan data yang berhubungan dengan pasien untuk menegakkan diagnosa keperawatan, kemampuan pasien, dan rencana yang efektif dalam perawatan pasien.Data-data yang akan diperoleh saat melakukan pengkajian pada klien yaitu Pertama, Data Dasar yaitu data yang memuat seluruh informasi tentang status kesehatan klien yang meliputi data umum, data demografi, riwayat keperawatan, pola fungsi kesehatan dan pemeriksaan.

Pembahasan

Penerapan asuhan keperawatan di Rumah Sakit merupakan suatu upaya dan tindakan dalam memberikan pelayanan yang baik terhadap pasien dimana dalam memberikan asuhan keperawatan perlu diperhatikan beberapa aspek sebelum 
melakukannya. Mengenai hubungan penerapan dan penatalaksanaan asuhan keperawatan di rumah sakit dilakukan dengan cara pemenuhan kebutuhan spiritual pada pasien di ruang rawat rumah sakit .Dengan menerapkan asuhan keperawatan ini perawat harus mampu mengetahui masalah kondisi kesehatan pada pasien sebelum melakukan pengkajian terhadap pasien dengan begitu perawat dapat lebih mudah menerapkan sistem asuhan keperawatan yang harus diberikan terhadap klien saat berada di Rumah Sakit.

Asuhan keperawatan adalah suatu pelayanan atau pendekatan dimna dalam untuk memecakan suatu masalah yang memampukan perawat dalam mengatur dan memberikan asuhan keperawatan kepada pasien. Dalam melakukan asuhan keperawatan harus memiliki standar asuhan dimana dalam standar praktik klinis dalam keperawatan yaitu terdiri dari pengkajian ,diagnosa ,perencanaan ,implementasi ,evaluasi. Dalam meningkatkan mutu pelayanan yang diberikan oleh perawat harus sesuai dengan tindakan prosedur yang sudah ditetapkan oleh pihak Rumah Sakit.

Penerapan asuhan keperawatan adalah dimana tugas dan peran seorang perawat harus melaksanakan tahap-tahap dalam memberikan asuhan keperawatan pada pasien. Dimana dalam memberikan asuhan keperawatan peran dan tanggung jawab seorang perawat sangat penting untuk memberikan pelayanan yang berkualitas terhadap klien yang menerima pelayanan tersebut. Pada penerapan asuhan keperawatan di Rumah sakit masih mengalami beberapa kendala dimana perawat belum mengetahui standar prosedur yang harus dilakukan dalam memberikan asuhan keperawatan terhadap pasien oleh karena itu peran perawat penting dalam melakukan penerapan dan pelaksanaan asuhan keperawatan di Rumah Sakit agar lebih mudah dalam memberikan pelayanan pada pasien di Rumah sakit.

Suatu tindakan dalam memberikan pelayanan keperawatan merupakan bagian dari pelayanan kesehatan yang berperan besar menentukan pelayanan kesehatan. Keperawatan sebagai profesi dan dimana perawat sebagai tenaga kerja profesional dan bertanggung jawab untuk memberikan pelayanan keperawatan sesuai kompetensi dan kewenangan yang dimiliki secara mandiri maupun bekerja sama dengan tenaga profesi kesehatan lainnya. Dimana dalam profesi keperawatan peran seorang perawat sebagai bagian integral dari sistem pelayanan kesehatan. Dengan memberikan asuhan keperawatan pada pasien bentuk kinerja oleh perawat 
harus profesional sesuai dengan tindakan prosedur yang ditetapkan. Asuhan keperawatan pasien harus diberikan melalui perawat yang harus mengetahui masalah kondisi kesehatan pasien tersebut terlebih dahulu agar lebih mudah memecahkan masalah yang terdapat pada kondisi pasien dengan begitu dapat diberikan asuhan keperawatan ataupun pelayanan terhadap pasien di Rumah Sakit.

Dalam memberikan pelayanan kepada masyarakat Rumah Sakit merupakan suatu bentuk upaya pemberian pelayanan yang berjasa dalam memberikan pelayanan kesehatan bagi masyarakat dimana setiap setiap tenaga kesehetan ataupun tenaga medis yang bekerja di Rumah akit harus mampu bekerja sama satu sama lain dalam memberikan pelayanan yang sesuai dengan standar pelayanan rumah sakit serta sesuai dengan prosedur yang sudah ditetapkan dalam memberikan pelayanan. Pelayanan asuhan keperawatan adalah suatu pendekatan dalam memberikan pelayanan dimana perawat berperan penting dalam proses memberikan jasa serta pelayanan yang baik terhadap pasien di rumah sakit.

Pendekatan yang dilakukan oleh seorang perawat yaitu dengan cara untuk memecahkan masalah terkait kondisi kesehatan yang dialami oleh pasien. Selain itu dalam memberikan asuhan keperawatan ini harus memperhatikan standar asuhan yang sudah tercantum dalam standar praktik klinis keperawatan yang dimana terdiri dari pengkajian,diagnosa,perencanaan,implementasi dan evaluasi. Salah satu manfaat penting dalam menerapkan sistem asuhan keperawatan ini adalah untuk meningkatkan mutu serta kualitas pelayanan dalam bidang keperawatan. Standar prosedur pelayanan yang dilakukan dalam memberikan asuhan keperawatan adalah agar tenaga profesi kerja ataupun tenaga medis seperti perawat mampu memahami dan mengidentifikasi terkait masalah kondisi kesehatan pasien serta dapat memecahkan masalah terkait proses penyembuhan dan pemulihan.

Tenaga perawat mempunyai kedudukan penting dalam menghasilkan kualitas pelayanan kesehatan dirumah sakit.Asuhan keperawatan yang bermutu dapat tercapai dengan pelaksanaan proses keperawatan. Proses keperawatan dapat memberikan asuhan keperawatan yang sesuai dengan kebutuhan klien, sehingga tercapai mutu pelayanan keperawatan yang optimal (Suarli \& Bahtiar, 2009). proses keperawatan berperan dalam membantu perawat melakukan praktik keperawatan secara sistematis dalam memecahkan masalah keperawatannya. Dalam melaksanakan proses keperawatan dalam rangka menjalankan asuhan keperawatan sesuai standar diperlukan tahap pengkajian yang merupakan awal penentuan untuk 
langkah proses keperawatan selanjutnya. . Pengetahuan yang luas dan bertanggung jawab merupakan aspek penting yang harus dimiliki seorang perawat dalam melakukan pengkajian.

Tenaga kesehatan sebagai sumber daya manusia dalam menjalankan pelayanan kesehatan di rumah sakit merupakan sumber daya yang penting dan sangat di butuhkan untuk mencapai kinerja yang optimal. Berhasil tidaknya suatu perusahaan termasuk perusahaan yang bergerak dalam bidang jasa pelayanan kesehatan seperti rumah sakit tergantung pada kemampuan sumber daya manusia dalam menjalankan aktivitasnya. Pelayanan kesehatan di Indonesia, khususnya pelayanan kesehatan di rumah sakit saat ini sedang mendapat perhatian dari masyarakat. Pelbagai keluhan dari masyarakat yang menyangkut kualitas pelayanan di rumah sakit haruslah mendapat kepedulian dari pihak pengelola dan penyelenggara layanan rumah sakit. Kendala manajemen dan pelaksanaannya perlu untuk segera diatas atau diminimalkan.

Dalam Teknik pengumpulan data juga diperlukannya keterampilan perawat seperti mengajukan pertanyaan terbuka, menggali jawaban dan respon klien, menciptakan suasana yang nyaman bagi klien, serta membina hubungan saling percaya. Teknik pengumpulan data dapat dilakukan melalui metode wawancara, yaitu menjalin komunikasi perawat dengan klien, observasi, dan pemeriksaan fisik. Pada tahap akhir, perawat harus dapat melakukan pendokumentasian pengkajian keperawatan yang berisikan bukti catatan hasil pengkajian yang dilakukan untuk mengumpulkan segala informasi dari pasien, dan menuliskan data pasien, serta respon pasien yang berguna untuk kepentingan klien agar dapat menentukan rencana asuhan keperawatan klien selanjutnya.

Proses keperawatan merupakan metode ilmiah yang dipakai dalam memberikan asuhan keperawatan yang profesional. Perawat, dimana saja ia bertugas, menghadapi klien dengan segala macam kasus, dan melayani klien pada semua tingkat usia juga harus menggunakan proses keperawatan. Perawat diharapkan memahami tentang konsep proses keperawatan dan mampu menerapkan serta menyusunannya dalam sebuah dokumen status kesehatan klien (Rohmah, N dan Walid, S. 2009). Proses keperawatan adalah aktivitas yang 
mempunyai maksud yaitu praktik keperawatan yang dilakukan dengan cara yang sistematik. Selama melaksanakan proses keperawatan, perawat menggunakan dasar pengetahuan yang komprehensif untuk mengkaji status kesehatan klien, membuat penilaian yang bijaksana dan mendiagnosa, mengidentifikasi hasil akhir kesehatan klien dan merencanakan, menerapkan dan mengevaluasi tindakan keperawatan yang tepat guna mencapai hasil akhir tersebut (Dermawan, 2012).

Perencanaan juga merupakan petunjuk tertulis yang menggambarkan secara tepat mengenai rencana tindakan yang dilakukan terhadap pasien sesuai dengan tingkat kebutuhan berdasarkan diagnosa keperawatan yang muncul. Untuk itu rencana tindakan yang baik tentunya harus berdasarkan pada diagnosa keperawatan yang telah dirumuskan Tahap perencanaan merupakan suatu proses penyusunan berbagai intervensi keperawatan yang dibutuhkan untuk mencegah, menurunkan atau mengurangi masalah-masalah klien. tahap perencanaan bagi perawat diperlukan berbagai pengetahuan dan keterampilan diantaranya pengetahuan tentang kekuatan dan kelemahan klien, nilai dan kepercayaan klien, batasan praktek keperawatan, peran dari tenaga kesehatan lainnya, kemampuan dalam memecahkan masalah, mengambil keputusan, menulis tujuan serta memilih dan membuat strategi keperawatan yang aman dalam memenuhi tujuan, menulis instruksi keperawatan serta kemampuan dalam melaksanakan kerja sama dengan tingkat kesehatan lain.

\section{Penutup}

Pengkajian Keperawatan merupakan dasar pelaksanaan proses keperawatan. Pengkajian keperawatan dapat dimulai dengan melakukan pengumpulan data-data klien yang didapatkan dari berbagai sumber data dan teknik pengumpulan data yang berfungsi untuk mengenali dan mengidentifikasi kebutuhan dan permasalahan kesehatan yang dialami klien dan kemudian dituliskan dalam dokumentasi keperawatan. Maka dari itu, dibutuhkan perawat yang memiliki pengetahuan luas dan bertanggung jawab sehingga data yang dikumpulkan akurat dan relevan sesuai dengan kondisi permasalahan klien. Pengumpulan data sangat dibutuhkan dikarenakan data-data yang dikumpulkan melalui pengkajian keperawatan berperan besar dalam menentukan asuhan keperawatan klien selanjutnya.

Proses keperawatan merupakan suatu jawaban untuk pemecahan masalah dalam keperawatan, karena proses keperawatan merupakan metode ilmiah yang 
digunakan secara sistematis dan menggunakan konsep dan prinsip ilmiah dalam mencapai diagnosa masalah kesehatan pasien, merumuskan tujuan yang ingin dicapai, menentukan tindakan dan mengevaluasi mutu serta hasil asuhan keperawatan. Dalam pratiknya perawat menggunakan pengetahuannya tentang proses keperawatan untuk mengkaji kesehatan klien, menegakkan diagnosa, merencakan asuhan keperawatan, menerapkan dan mengevaluasi tindakan keperawatan yang diberikan.

Daftar pustaka

1. Achmadi, Lutfiani D.L. Pondaag, L. Babakal, A. (2015). Gambaran Tingkat Pengetahuan Perawat Dalam Penerapan Standar Asuhan Keperawatan Di Ruangan Rawat Inap Interna RSUD DATOE BHINANGKANG. E-journal Keperawatan (e-kp). Vol. 3(3).

2. Anggeria, Elis. Maria. (2018). Hubungan Supervisi Dengan Pelaksanaan Asuhan Keperawatan Di Ruang Rawat Inap Lantai 10 Rumah Sakit Umum Royal Prima Medan Tahun 2017. Jurnal JUMANTIK, Vol. 3(2). 78-97.

3. Astar, F., Hasmin, T., Ikhasan, K. (2015). Pengaruh Pelayanan Asuhan Keperawatan Terhadap Kepuasan Pasien Di Puskesmas Takalala Kabupaten Soppeng. Journal Of Management, 1 (2)

4. Budiono. (2016). Konsep Dasar Keperawatan.Jakarta : Kementerian Kesehatan Republik Indonesia.

5. Damanik, M., Rahmi, F., Leni, M. (2019). Gambaran Keakuratan Dokumentasi Asuhan Keperawatan. Jurnal Kesehatan Andalas, 8(4)

6. Kasim, Mohamad. Abdurrouf, Muh. (2016). Peningkatan Kualitas Pelayanan dan Pendokumentasian Asuhan Keperawatan Dengan Metode Tim. Nurse Line Journal. Vol. 1(1). 62-72.

7. Putra, A, A., Sri, R., Tri, N, K. (2016). Hubungan Persepsi Perawat Tentang Karakteristik Pekerjaan Dengan Kepatuhan Dalam Pendokumentasian Asuhan Keperawatan. Jurnal Keperawatan Notokusumo, IV (1).

8. Rahayu, C, D., Sri, M. (2020). Pengambilan Keputusan Klinis Perawat. Jurnal IImiah Kesehatan, hal 1-11

9. 5). Simamora, N, F. (2019). Sifat Dan Tahap-Tahap Dalam Proses 
Keperawatan. Osf.io

10. Simamora, R. H. (2019). Development of Guidelines for Applying appropriate Patient Identification to Achieve Patient Safety Goal INC2019 12th International Nursing Conference. 2019.10455 - 455 (1 pages) UCI(KEPA) : I410-ECN-0101-2019-512-001224337

11. Wirawan, E,A., Dwi, N., Fiki, W. (2013). Hubungan Antara Supervisi Kepala Ruang Dengan Pendokumentasian Asuhan Keperawatan Di Rumah Sakit Umum Daerah Ambarawa. Jurnal Managemen Keperawatan, 1 (1).

12. Wirdah, H. Yusuf, M. (2016). Penerapan Asuhan Keperawatan oleh Perawat Pelaksana Di Rumah Sakit Banda Aceh. Jim Unsyiah. Vol. 1(1). 1-6. 